\title{
Pengembangan Bisnis Fashion Muslim Dengan Pendekatan Business Model Canvas (BMC)
}

\author{
Isnurrini Hidayat Susilowati \\ Universitas Bina Sarana Informatika \\ e-mail: isnurrini.ihs@bsi.ac.id

\begin{tabular}{ccc}
\hline Diterima & Direvisi & Disetujui \\
$16-08-2021$ & $23-08-2021$ & $02-09-2021$ \\
\hline
\end{tabular}

\begin{abstract}
Abstrak - Dampak pandemi covid 19 sangat dirasakan oleh semua sektor usaha termasuk sektor fashion. Oleh karena itu dibutuhkan strategi-strategi pengembangan bisnis agar usaha sektor fashion tetap bisa bertahan. Nayla Collection adalah salah satu usaha sektor UMKM dibidang fashion muslim dikota Depok dan agar usaha bisa bertahan dan berkembang dalam masa pandemi covid 19 ini maka harus mempunyai strategi bisnis. Strategi yang digunakan adalah dengan menggunakan alat bantu Business Model Canvas (BMC). Penelitian dilakukan menggunakan deskriptif kualitatif dengan data primer dan sekunder. Tujuan penelitian adalah untuk mengetahui strategi untuk mengembangkan bisnis melalui Business Model Canvas (BMC), dianalisa menggunakan SWOT (Strenght, Weakness, Oportunity dan Threat) . Penelitian yang dihasilkan disertai hasil dari analisa SWOT adalah strategi perbaikan dengan penambahan mitra dengan perusahaan e-commerce, pembuatan web untuk promosi produk dan bekerjasama dengan komunitas ibu-ibu muda. Mengedukasi pelanggan dalam mengkombinasikan produk yang akan dikenakan merupakan penambahan elemen value proposition. Pemilik toko fashion muslim Nayla Collection bisa menjadikan hasil penelitian tersebut sebagai pedoman dalam mengembangkan bisnisnya.
\end{abstract}

Kata Kunci: Analisis Bisnis, Analisis SWOT, Business Model Canvas

\begin{abstract}
The impact of the COVID-19 pandemic has been felt by all business sectors, including the fashion sector. Nowadays, business development strategies are needed; so that, the fashion sector business still can survive. Nayla Collection is one of the UMKM business sectors in the Moslem fashion sector in the city of Depok. In order to survive and thrive at these pandemic periods, it must have a great business strategy. The purpose of the research is to find out the strategy to develop the business. The strategy used is to use the Business Model Canvas (BMC) tools. The research was conducted by using qualitative research, using primary and secondary data. Moreover, the study used the Business Model Canvas (BMC), analyzed using SWOT (Strength, Weakness, Opportunity and Threat). The research produced along with the results of the SWOT analysis is an improvement strategy by adding partners with e-commerce companies, creating a web for product promotions and collaborating with the community of young mothers. Educating customers in combining products to be worn is an additional element of the value proposition. The owner of the Nayla Collection Moslem fashion store can use the results of the research as a guidance in developing their business.
\end{abstract}

Keywords : Business Analysis, Business Model Canvas, SWOT Analysis

\section{PENDAHULUAN}

Tahun 2020 telah terjadi goncangan ekonomi yang sangat luar biasa dengan munculnya pandemi covid 19. Karena hampir seluruh dunia mengalami serangan virus tersebut maka diputuskan oleh badan kesehatan dunia (WHO) menjadi pandemic global. Hal ini menyebabkan terjadi penurunan pergerakan di semua sektor di Indonesia terutama sektor ekonomi termasuk dalam kegiatan Usaha Mikro, Kecil dan Menengah (UMKM). (Aryansyah, Mirani, \& Martina, 2020)

Menurut (Bank Indonesia, 2021) sektor UMKM di Indonesia mencapai 99,99\% dari populasi perusahaan di Indonesia yaitu sebesar 62,9 juta unit sedangkan sisa nya adalah perusahaan besar dengan tenaga kerja sebesar 116,63 juta tenaga kerja disektor ini. Sumbangan sektor UMKM terhadap PDB konstan adalah sebesar 55,6 \% dan 37,06\% disumbang oleh perusahaan besar. Tahun 2019 peran sektor UMKM pada industry halal terdapat 1.107.955 perusahaan bergerak disektor fashion dimana $70 \%$ merupakan UMKM dan $30 \%$ adalah produsen pakaian muslim. Dengan melihat tingginya peranan sektor UMKM terhadap perekonomian secara keseluruhan terutama dalam sektor fashion perlu dilakukan strategi pengembangan bisnis, terutama dalam menghadapi pandemic covid 19 dimana 
sampai dengan tahun 2021 kasus covid 19 tetap tinggi bahkan meningkat dipertengahan tahun 2021.

Dampak pandemi covid 19 sangat dirasakan oleh semua sektor usaha termasuk sektor fashion. Oleh karena itu dibutuhkan strategi-strategi pengembangan bisnis agar usaha sektor fashion tetap bisa bertahan. Strategi dilakukan baik secara offline maupun online. Secara offline dibutuhkan kemampuan seperti penjualan dengan bazar secara periode. Sedangkan secara online bisa menggunakan media online untuk meningkatkan penjualan produk dan agar konsumen terdorong lebih sering berbelanja. (Candraningrat, Yurisma, \& Mujanah, 2021)

Pada penelitian terdahulu tentang penerapan Business Model Canvas pada E-Commerce Toko H5 Jayapura untuk menghasilkan e-commerce sehingga model bisnis yang ada diubah menjadi model bisnis berbasis e-commerce. Diharapkan dengan model bisnis yang baru akan meningkatkan penjualan dan membantu pelanggan melakukan pembelian secara online melalui e-commerce. (Annas, Jufri, \& Jusmawati, 2021)

Nayla Collection adalah salah satu usaha sektor UMKM dibidang fashion muslim yang melakukan penjualan produk-produk baju muslim wanita di kota Depok. Dengan terjadinya pandemic covid 19 dari awal tahun 2020 dan penerapan PPKM (Pemberlakuan Pembatasan Kegiatan Masyarakat) pada tahun 2021 menyebabkan omzet penjualan menjadi tidak berkembang. Transaksi mengalami kenaikan hanya pada bulan Mei disebabkan adanya perayaan Idhul Fitri dan untuk bulan Juni mengalami penurunan drastis seperti terlihat pada tabel 1 berikut ini.

Tabel 1. Omzet Penjualan Baju Muslim Nayla Collection Tahun 2021 (Rp)

\begin{tabular}{|c|c|}
\hline Bulan & Omzet Penjualan \\
\hline Januari & $15,869,000$ \\
\hline Pebruari & $34,764,000$ \\
\hline Maret & $31,400,000$ \\
\hline April & $17,900,000$ \\
\hline Mei & $43,900,000$ \\
\hline Juni & $10,256,000$ \\
\hline
\end{tabular}

Sumber : Nayla Collection (2021)

Omzet penjualan Nalya Collection tidak stabil pada saat memasuki tahun 2021. Bulan Februari sempat mengalami kenaikan lebih dari $119 \%$, tetapi dibulan berikutnya turun dan bulan April mengalami penurunan sebesar 43\%. Dan di bulan Juni mengalami penurunan drastis sebesar $77 \%$.

Dengan kondisi seperti itu, agar bisnis tetap bisa bertahan dan berkembang dibutuhkan strategi bisnis yang tepat. Agar Nayla Collection bisa bertahan dan berkembang dalam menjual produk busana muslim dalam masa pandemi ini maka harus mempunyai strategi bisnis. Menurut Chesbrought dalam (Ermaya \& Darna, 2019) dalam penelitiannya tentang strategi pengembangan bisnis dengan pendekatan Business Model Canvas (Studi Kasus: Industri Kecil Kerupuk) bahwa yang menjadi latar belakang penelitian ini adalah bahwa terdapat ancaman dari kompetiror dalam penjualan barang yaitu dengan harga lebih murah. Oleh karena itu penelitian tersebut menyatakan bahwa pengkajian dan perumusan model bisnis yang tepat merupakan dasar dari strategi usaha yang dijalankan perusahaan sehingga strategi usaha tersebut bisa berjalan dengan maksimal. Pada penelitian sebelumnya tentang Business Model Canvas sebagai alat bantu dalam menentukan strategi bisnis pada toko retail pakaian, menyatakan bahwa pendapatan bulanan jarang mencapai target kecuali pada bulan tertentu seperti bulan Ramadhan. Oleh karena itu diperlukan strategi bisnis untuk meningkatkan penjualan toko agar melebihi target. (Sukarno \& Ahsan, 2021) Pada penelitian sebelumnya tersebut perbaikan BMC diambil dari analisa SWOT dari sisi faktor internal dan eksternalnya.

Alat bantu yang digunakan dalam penelitian ini untuk menentukan strategi bisnis adalah menggunakan Business Model Canvas (BMC), fokus dalam menentukan strategi bisnis dari elemenelemennya. Dalam penelitian ini perbaikan strategi bisnis BMC menggunakan strategi dari analisa SWOT nya. Tujuan dari penelitian ini adalah untuk mengetahui strategi untuk mengembangkan bisnis melalui Business Model Canvas (BMC)

\section{Business Model Canvas (BMC)}

Perusahaan dalam melakukan interaksi dengan pemasok, modal kerja dan pelanggan dapat dilakukan dengan konsep model bisnis, dimana penciptaan nilai dalam organisasi dapat diperoleh dengan penggambaran dasar pemikiran hal tersebut. (Wardhanie \& Kumalawati, 2018) Dalam menciptakan nilai dan manfaat dari pelanggan dibuat kerangka bisnis model terdiri dari sembilan kotak yang saling berhubungan.

Customer segments merupakan sekelompok masyarakat yang memakai produk dan mempunyai kontribusi dalam memberikan penghasilan untuk perusahaan dimana pelanggan di bagi-bagi berdasarkan umur, perilaku, penghasilan, profesi dan geografi. Value propositions adalah keunikan suatu produk sehingga produk dipilih oleh pelanggan. Channel dalam menyampaikan value proposition menggunakan cara berkomunikasi dengan pelanggan. Customer relationship merupakan pembinaan hubungan dengan pelanggan dengan tujuan untuk mendapatkan pelanggan baru dan mempertahankan pelanggan lama. Revenue stream menjelaskan bagaimana perusahaan memperoleh penghasilan dari setiap customer segments.

Sementara itu, key resiurces merupakan asset-aset terpenting dalam menentukan keberhasilan operasional model bisnis. Kegiatan utama yang menunjang keberhasilan suatu model bisnis dalam 
mengirimkan value proposition nya ke pelanggan dinamakan key activities. Key partnership adalah kesepakatan kerjasama bisnis antara dua atau lebih perusahaan dalam menyelesaikan proyek tertentu untuk penghematan biaya dan mengurangi risiko. Sedangkan cost structure menggambarkan semua biaya yang muncul karena operasional model bisnis dalam mewujudkan value proposition melalui channel, key resources, key activities yang tepat. (Wardhanie \& Kumalawati, 2018)

\section{Analisa Strength, Weakness, Opportunities, Threats (SWOT)}

Analisa Strength, Weakness, Opportunities, Threats (SWOT) merupakan evaluasi pada semua kekuatan dan kelemahan dari faktor internal usaha dan evaluasi dari peluang dan ancaman yang merupakan faktor eksternal usaha. Analisa ini berkaitan erat dengan BMC. (Kotler \& Keller, 2016)

Strategi Strength Opportunity menggunakan kekuatan internal perusahaan untuk meraih peluangpeluang yang ada diluar perusahaan, Jika perusahaan memiliki banyak kelemahan, perusahaan harus mengatasi kelemahan agar kuat. Sedangkan jika menhadapi banyak ancaman maka perusahaan harus berusahan menghindarinya dan berusaha berkonsentrasi pada peluang-peluang yang ada. Strategi weakness opportunity untuk memperkecil kelemahan-kelemahan internal perusahaan dengan memanfaatkan peuang-peluang eksternal. Strategi strength Threat untuk menghindari atau menguarangi dampak dari ancaman eksternal perusahaan sedangkan weakness threats merupakan cara bertahan dengan mengurangi kelemahan internal serta menghindari ancaman. (Umar, 2019)

\section{METODE PENELITIAN}

Penelitian dilakukan pada toko busana muslim Nayla Collection yang berlokasi didaerah strategis di kota Depok. Penelitian menggunakan metode deskriptif kualitatif dimana metode yang digunakan dalam penelitian ini menggunakan objek alamiah dalam instrument kunci, pengambilan sumber data dilakukan dengan purposive dan bersifat kualitatif. Proses dalam penelitian diutamakan daripada hasil dan hasil penelitian disetujui oleh peneliti dan subjek penelitian. Data yang dikumpulkan menggunakan Teknik wawancara atau pengamatan terkait dengan masalah yang diteliti. (Sugiyono, 2014) Data primer diambil dari hasil wawancara dengan pemilik dan pembeli toko baju muslim Nayla Collection. Pembeli yang dijadikan responden sebanyak 35 responden dipilih secara purposive. Data-data yang terkumpul diamati, dianalisis dan dihubungkan dengan teori yang menjadi landasannya.

\section{HASIL DAN PEMBAHASAN}

\section{Business Model Canvas (BMC)}

Identifikasi BMC pada toko fashion muslim Nayla Collection adalah sebagai berikut :

a. Key Partnership. Usaha Nayla Collection tidak dapat berjalan bila tidak bermitra dengan pihak ketiga. Pihak-pihak yang bisa diajak kerjasama dengan Nayla Collection adalah supplier yang melakukan usaha perdagangan di Tanah Abang, dan supplier tersebut memproduksi sendiri baju. Untuk pengiriman penjualan produk melalui online, terdapat pihak jasa pengiriman barang dan perusahaan penyediaan transportasi online.

b. Key Activities. Kegiatan wajib yang dilakukan perusahaan agar model bisnis nya bisa bekerja, menarik pelanggan baru dan mempertahankan pelanggan. Berdasarkan hasil wawancara, yang dilakukan oleh nayla collection adalah membeli produk baju muslim yang menarik dan up to date dari supplier, didisplay di toko dan promosi melalui media sosial.

c. Key Resources. Hal-hal penting yang harus dimiliki perusahaan agar key activities bisa dilakukan. Berdasarkan wawancara dan observasi, sumber daya fisik yang dimiliki nayla collection adalah ruko tempat menjual produk dan alat-alat display baju muslim serta ruangan ganti baju. Sedangkan sumber daya non fisik (intelektual), usaha penjualan fashion muslim ini belum mempatenkan merk nayla collection, namun sudah memiliki database pelanggan meskipun masih tercatat secara konvensional. Tentang sumber daya manusia, nayla collection memiliki 2 karyawan untuk membantu kegiatan usahanya. Berdasarkan hasil wawancara, nayla collection memiliki sumber modal yang berasal dari modal sendiri. Untuk pengelolaan keuangan, dimana mengatur arus masuk dan keluar kas diatur oleh pemilik nayla collection dan pencatatannya masih menggunakan cara manual.

d. Value Proposition. Menurut Osterwalder dan Pigneur dalam value proposition adalah nilai yang diciptakan dari produk dan layanan untuk segmen pelanggan (Ermaya \& Darna, 2019). Nayla Collection adalah usaha penjualan baju muslim dengan model kekinian, modern dan up to date dengan harga terjangkau. Pembeli yang datang langsung ke toko dilayani dengan ramah oleh karyawan yang berjumlah 2 orang. Pembeli juga tidak harus datang ke toko offline tetapi bisa menggunakan fasilitas online. Lokasi toko offline mudah dijangkau karena berada di pinggir jalan dan pelanggan yang tidak datang ke toko offline bisa memilih produk dengan 
menggunakan media sosial seperti Instagram, facebook dan whatsapp.

e. Customer Relationship. Hubungan dengan pelanggan yang dibangun Nayla Collection adalah dengan memberikan diskon pada weekend dengan mengadakan bazar produk tertentu dengan potongan harga. Nayla Collection juga selalu memberikan info-info produk baru dan diskon melalui media sosial seperti Instagram, facebook dan whatsapp. Untuk offline juga terdapat personal assistant yang melayani pembelian langsung di toko.

f. Channel. Nayla Collection menggunakan dua saluran, dimana menggunakan media sosial dalam menginformasikan value proposition kepada pelanggan (instragam, facebook dan whatsapp) dan testemoni dari pelanggan tentang produk baju muslim. Sedangkan saluran langsung diberikan kepada pembeli yang datang ke toko.

g. Customer Segmen. Target market dari penjualan produk baju muslim Nayla Collection adalah Wanita kalangan menengah keatas, remaja Wanita dan ibu-ibu muda yang trendy.

h. Cost Structure. Biaya yang dikeluarkan oleh perusahaan dalam menghasilkan value proposition. Biaya yang dikeluarkan oleh Nayla Collection adalah biaya pembelian produk baju muslim, biaya karyawan, listrik dan air serta biaya pemasaran.

i. Revenue Stream. Pendapatan utama dari Nayla Collection adalah penjualan dari produk baju muslim dan hasil pembelian produk masih dilakukan dengan cash. 


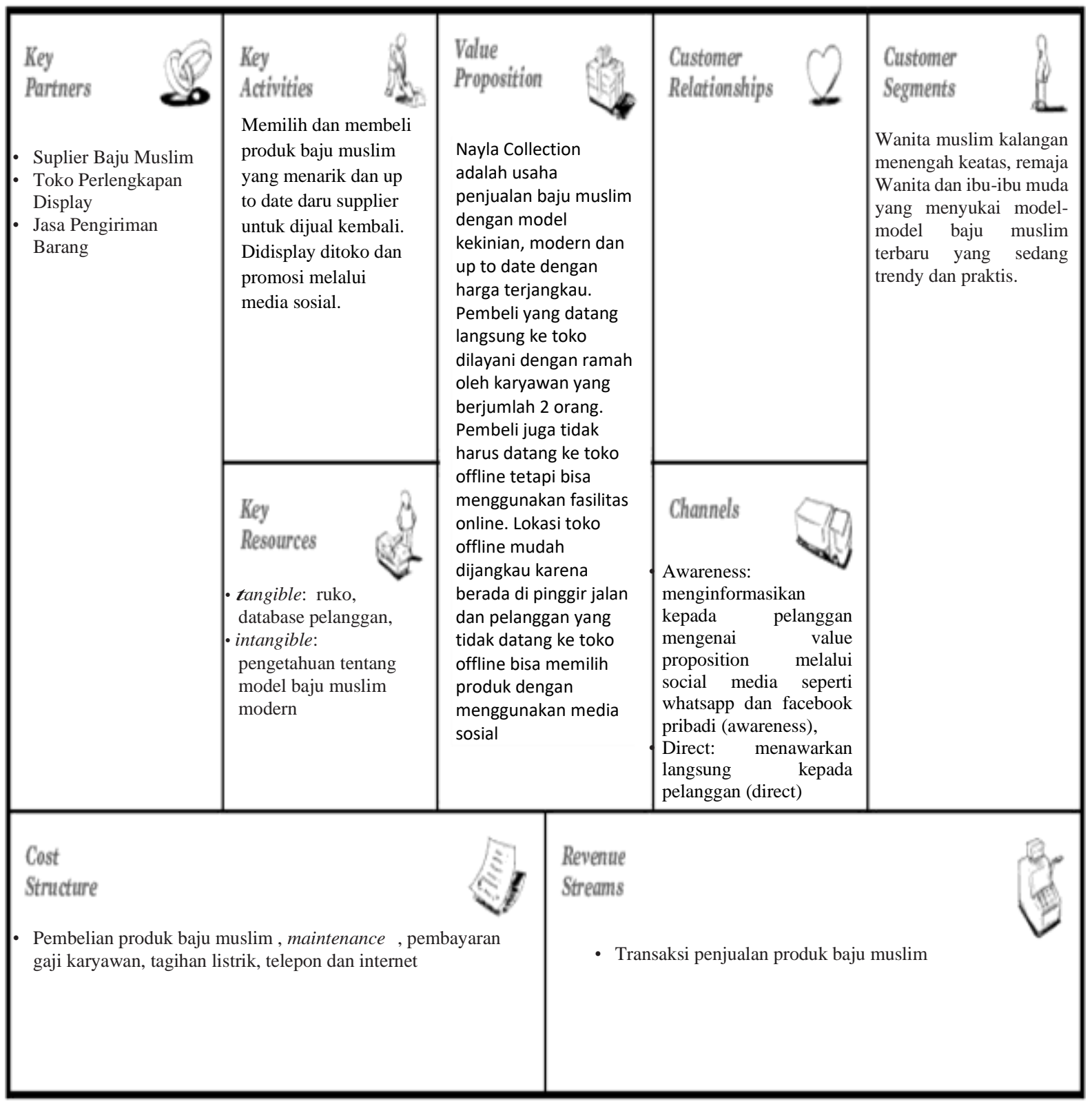

Sumber : Data diolah (2021)

Gambar 1 : BMC Nayla Collection Yang Sedang Berjalan

\section{Analisa SWOT}

Setelah melakukan identifikasi dengan menggunakan BMC pada sembilan elemen yang dimiliki oleh Nayla Collection, yang dilakukan selanjutnya adalah melakukan identifikasi berdasarkan analisis SWOT untuk mengidentifikasikan kekuatan, kelemahan, peluang dan ancaman yang dialami perusahaan. Analisa SWOT pada toko baju muslim Nayla Collection dapat dilihat pada tabel 2 sebagai berikut :

Tabel 2. Analisa SWOT Toko Fashion Muslim Nayla Collection

Kekuatan (Strength) Kelemahan (Weakness)

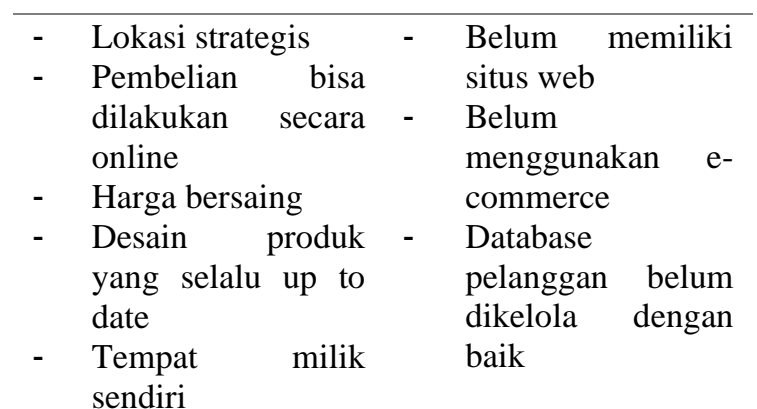

Peluang Ancaman (treath)

(Opportunities) 


\begin{tabular}{lll}
\hline Lokasi berdekatan & - & $\begin{array}{l}\text { Munculnya bisnis } \\
\text { sejenis dan dengan } \\
\text { dengan pemukiman }\end{array}$ \\
penduduk dan & system yang sejenis & Munculnya pesaing \\
pengan inovasi baru & denan & Pandemi Covid 19 \\
Meningkatnya & yang belum berakhir \\
kesadaran akan & - & Perubahan selera \\
model baju muslim & masyarakat \\
yang fashionable &
\end{tabular}

Sumber : Data diolah (2021)

Dari tabel 2 bisa dijelaskan bahwa terdapat kekuatan dari Toko Nayla Colletion yaitu tempat yang strategis. Toko terletak dipinggir jalan yang ramai dilalui baik angkutan umum maupun pribadi. Pembelian produk tidak harus datang ke lokasi atau toko tetapi bisa melalui online seperti whatsapp, Instagram dan Facebook. Harga yang ditetapkan bersaing dan terjangkau untuk kalangan menengah keatas. Toko Nayla Collection selalu memantau produk busana muslim yang diminati masyarakat pada saat ini dengan memahami perilaku dan selera pelanggannya. Lokasi toko Nalya colletion merupakan tempat milik sendiri sehingga perusahaan mempunyai kekuatan dalam menghadapi permasalahan penurunan penjualan dalam satu tahun terakhir dikarenakan pandemic covid 19 dikarenakan tidak perlu mengeluarkan biaya untuk pembayaran sewa toko yang cukup tinggi.

Kelemahan dari toko Nayla Collection adalah belum memiliki web, sehingga target pemasarannya belum bisa menjangkau yang lebih luas.. Kelemahan selanjutnya adalah belum bekerjasama dengan e-commerce seperti Lazada, Sophee dan Toko Pedia dalam melakukan penjualan peroduknya. Media pemasaran online hanya menggunakan whatsapp, Instagram dan facebook. Toko Nalya Collection belum memiliki database pelanggan yang baik, sehingga belum bisa membuat program yang bertujuan membangun hubungan pelanggan.

Kedua kekuatan dan kelemahan toko fashion muslim Nayla Collection tersebut merupakan faktor internal, sedangkan faktor eksternal dari bisnis ini dilihat dari peluang dan ancaman dari luar perusahaan.

Peluang yang dimiliki oleh toko fashion muslim Nayla Colletion adalah lokasi toko terletak dilokasi yang padat penduduk dan terdapat perumahan seperti perumahan Puri Hasanah. Peluang selanjutnya adalah adanya kesadaran para Wanita dalam berbusana muslim yang up to date dan fashionable. Model busana yang akan dikenakan disesuaiakan dengan acara yang akan dhadiri.

Dalam melakukan usahanya, toko fashion muslim Nalya Collection mempunyai ancaman yaitu munculnya bisnis sejenis dan dengan system yang sejenis maka terdapat kemungkinan pelanggan akan beralih ke pesaing. Kemudian muncul pesaing dengan inovasi produk baru yang lebih cepat dibandingkan dengan Nalya Collection. Seperti diketahui bahwa pergantian atau inovasi model baju muslim sangat berkembang dengan cepat untuk memenuhi keinginan konsumen. Dengan pandemic covid 19 yang muncul dari awal tahun 2020 menyebabkan menurunnya daya beli masyarakat karena ada kebijakan-kebijakan pemerintah seperti PPKM (Perberlakuan Pembatasan Kegiatan Masyarakat). Bila pandemic tidak bisa segera diatasi oleh pemerintah dikuatirkan akan semakin menurun penjualan produknya. Perubahan selera masyarakat terhadap model baju muslim merupakan ancaman bila Nayla Collection tidak bisa memenuhi selera pelanggan yang disebabkan efek dari globalisasi dari sisi fashion.

Strategi yang dilakukan dengan kekuatan internal dengan mempertemukan kekuatan- peluang adalah dengan memperluas pemasaran produk ke perumahan maupun masyarakat disekitar toko misalnya dengan membuat program diskon untuk produk. Nalya Collection harus selalu update model model fashion muslim yang sedang disukai masyarakat dan untuk pembelian secara offline bisa mendapatkan edukasi dalam cara berpakaian yang fashionable. Strategi kelemahan-peluang dilakukan dengan tujuan memperkecil kelemahan-kelmahan internal perusahaan yaitu dengan bekerja sama dengan pelaku e-commerce seperti Lazada, Shopee dan Toko Pedia (Toped) sehingga masyarakat yang menginginkan model fashion muslim terkini bisa dengan mudah mendapatkan dengan pembelian melalui e-commerce. Selain itu dengan dibuat situs web Nayla Collection.

Sedangkan Strategi untuk kekuatan-ancaman yang dilakukan dengan mempertahankan kualitas produk dan selalu up to date model busana muslim sehingga pelanggan tidak akan berpindah ke pesaing. Meningkatkan pelayanan kepada pelanggan juga harus ditingkatkan seperti lamanya pengiriman produk bila pembelian secara online. Strategi penentuan harga supaya bisa bersaing dengan kualitas dan model baju yang tetap mengikuti perkembangan jaman. Selalu upload di media sosial model-model baju terbaru ataupun model lama dengan kemasan yang menarik. Untuk strategi selanjutnya dari analisa kelemahan-ancaman adalah memperbaiki strategi bisnis yang lebih baik misalnya dengan bekerja sama dengan e-commerce dalam melakukan penjualan produk. Mengembangkan sumber daya manusia agar bisa selalu mengikuti perkembangan model fashion secara global. Promosi selalu gencar dilakukan baik melalui offline maupun online baik promosi produk maupun cara pembelian produk sehingga meskipun dalam kondisi pandemic covid 19 masyarakat tetap bisa melakukan pembelian produk secara online. Promosi bisa dilakukan dengan memperkuat database pelanggan sehingga bila ada promo diskon bisa segera diinformasikan kepada pelanggan dan 
merangkul komunitas ibu-ibu muda sesuai target market nya.

\section{BMC Perbaikan}

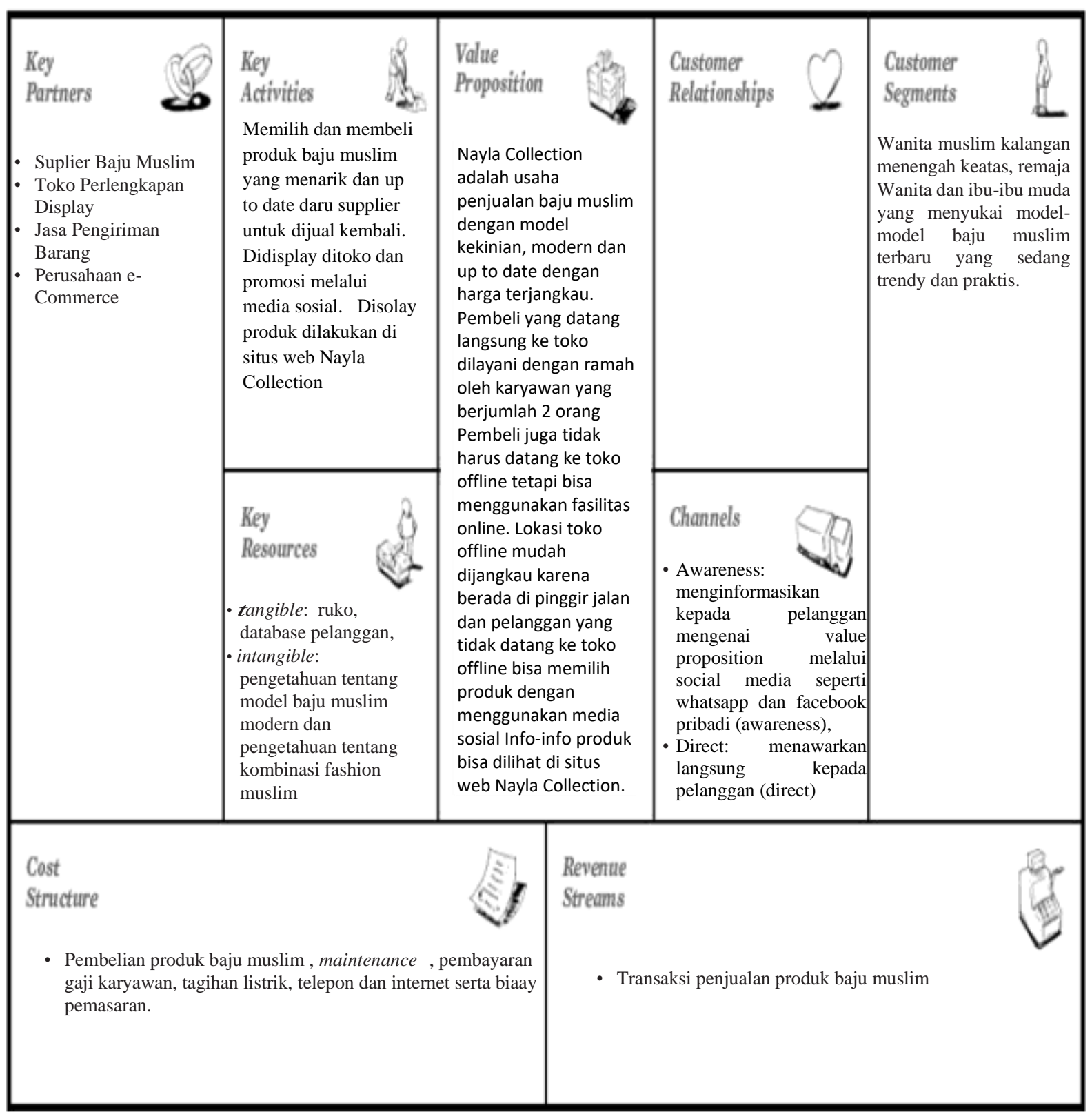

Sumber : Data diolah (2021)

Gambar 2. BMC Perbaikan Nayla Collection

BMC perbaikan dibuat agar bisnis Nayla Collection tetap bisa berkembang meskipun dalam kondisi pandemic covid 19. Dengan mempertimbangkan BMC yang sedang berjalan dan analisa SWOT nya, berdasarkan FGD diperoleh BMC perbaikan seperti pada gambar 2 .

Identifikasi BMC perbaikan adalah sebagai berikut :
1. Key Partnership, dalam bermitra dengan pihak lain terdapat penambahan untuk bekerja sama dengan perusahaan e-commerce dalam penjualan produknya seperti Lazada, Bukalapak, Shopee dan Toko Pedia. Strategi ini sesuai dengan strategi kelemahan dan peluang sehingga bisa meminimalisir kelemahan dengan peluang yang ada. 
2. Key Activities. Kegiatan wajib yang dilakukan perusahaan agar model bisnis nya bisa bekerja, menarik pelanggan baru dan mempertahankan pelanggan. Berdasarkan hasil FGD maka promosi promosi produk bisa ditambahkan melalui situs web Nayla Collection.

3. Key Resources, sebagai tambahannya adalah dengan memberikan pelatihan kepada karyawan tentang pemakaian fashion muslim modern sehingga karyawan bisa memberikan edukasi kepada pembeli tentang padu padan yang sebaiknya dipakai oleh pelangan.

4. Value Proposition. Terdapat penambahan dengan dibuat situs web Nayla Collection sehingga info-info produk barang bisa dilihat oleh pelanggan secara lengkap yang merupakan salah satu strategi kelemahan - peluang. Kemudian untuk mengakomodir kebutuhan pelanggan akan padu padan model baju yang cocok, selain karyawan harus melayani dengan ramah, karyawan juga bisa memberikan edukasi cara mencocokkan pemakaian busana muslim yang akan dikenakan sehingga terlihat elegan.

5. Customer Relationship. Hubungan dengan pelanggan selain melalui media sosial seperti Instagram, facebook dan whatsapp juga bisa ditambahkan dengan bekerja sama dengan perusahaan e-commerce dan menjalin hubungan dengan komunitas-komunitas ibu-ibu muda seperti komunitas kelompok senam dan pengajian ibu-ibu disekitar toko dan perumahanperumahan.

6. Channel. Pada elemen ini bisa ditambahkan melalui komunitas-komunitas ibu-ibu muda.

7. Customer Segmen. Pada elemen ini tidak ada penambahan, masih sama dengan BMC yang sedang berjalan.

8. Cost Structure. Biaya yang dikeluarkan oleh perusahaan dalam menghasilkan value proposition. Terdapat penambahan biaya untuk biaya pemasaran yang digunakan untuk biaya ecommerce.

9. Revenue Stream. Pendapatan utama dari Nayla Collection adalah penjualan dari produk baju muslim dan hasil pembelian produk masih dilakukan dengan cash serta tidak ada penambahan sumber pendapatan.

\section{KESIMPULAN}

Customer segments toko fashion muslim Nayla Collection dikota Depok adalah wanita kalangan menengah keatas, remaja Wanita dan ibuibu muda yang trendy dengan menawarkan value propositions yang meliputi produk baju muslim yang modern dan kekinian dengan harga terjangkau. Untuk menyampaikan value yang ditawarkan maka Nayla Collection menggunakan channel penjualan langsung dan menggunakan customer relationship berupa whatsapp, Instagram dan facebook. Agar dapat menghasilkan value dilakukan beberapa key activities yang meliputi kegiatan pemebelian produk baju muslim dari supplier kemudian di display dan dijual kembali dengan memanfaatkan key resources yang meliputi ruko, alat untuk display produk serta ruangan ganti baju.Agar aktifitas dapat berjalan untuk menghasilkan value yang diharapkan Nayla Collection memiliki key partners yang terdiri supplier, toko perlengkapan display produk dan jasa pengiriman barang menghasilkan revenue streams dari penjualan baju muslim dengan cost structure biaya tetap dan biaya variabel.

Hasil analisi SWOT menunjukkan bahwa Strategi yang dilakukan dengan kekuatan internal dengan mempertemukan kekuatan- peluang adalah dengan memperluas pemasaran produk ke perumahan maupun masyarakat disekitar toko. Strategi kelemahan-peluang dilakukan dengan tujuan memperkecil kelemahan-kelmahan internal perusahaan yaitu dengan bekerja sama dengan pelaku e-commerce. Sedangkan Strategi untuk kekuatanancaman yang dilakukan dengan mempertahankan kualitas produk dan selalu up to date model busana muslim. Strategi selanjutnya dari analisa kelemahanancaman adalah memperbaiki strategi bisnis yang lebih baik. Dalam penelitian ini hanya menganalisa satu produk fashion muslim, diharapkan dalam penelitian selanjutkan adalah dengan membandingkan berbagai bidang fashion disektor UMKM sehingga dapat bermanfaat untuk sektor UMKM di Indonesia.

Desain perbaikan BMC Nayla Collection sebagai strategi pengembangan perusahaan perlu dilakukan dengan melakukan penambahan pada elemen key partnership dengan bermitra dengan perusahaan e-commerce. Key Activities, ditambahkan dengan membuat situs web untuk promosi produk. Untuk elemen key Key Resources, ditambahkan memberikan pelatihan kepada karyawan tentang fashion. Sedangkan tambahan untuk elemen value Proposition adalah dengan mengedukasi pembeli dalam mempadupadankan busana muslim yang akan dikenakan. Bekerja sama dengan perusahaan ecommerce merupakan tambahan pada elemen Customer Relationship. Komunitas-komunitas ibuibu muda ditambahkan untuk elemen channel.

\section{Referensi}

Annas, A., Jufri, M. T., \& Jusmawati. (2021). Penerapan Business Model Canvas Pada ECommerce Toko H5 Jayapura. JSAI : Journal Scientific and Applied Informatics, 204-220, Vol. 4 No. 2, https://doi.org/10.36085/jsai.v4i2.1671. 
Aryansyah, E. J., Mirani, D., \& Martina. (2020). Strategi Bertahan Usaha Mikro Kecil Dan Menengah . AvoEr 12, 323-329.

Bank Indonesia. (2021, July 18). Retrieved from Bank Indonesia: http://www.bi.co.id

Candraningrat, Yurisma, D. Y., \& Mujanah, S. (2021). Pengembangan Strategi Bisnis Melalui Bmc (Business Model Canvas). Tekmulogi: Jurnal Pengabdian Masyarakat, 16-24, Vol. 1 No. 1 , https://ejournal.upi.edu/index.php/Tekmulo gi/article/view/34295.

Ermaya, S. K., \& Darna, N. (2019). Strategi Pengembangan Bisnis Dengan Pendekatan Business Model Canvas (Studi Kasus: Industri Kecil Kerupuk). Business Management And Entrepreneurship Journal, 201 -218, Vol. 1 No. 3, https://jurnal.unigal.ac.id/index.php/bmej/is sue/view/301.

Kotler , P., \& Keller, K. L. (2016). Manajemen Pemasaran Edisi 12 Jilid 1. Jakarta: PT Indeks.

Sugiyono. (2014). Metode Penelitian Kuantitatif, Kualitatif dan $R$ \& $D$. Bandung: CV Alfabeta.

Sukarno, B. R., \& Ahsan, M. (2021). Implementasi Strategi Pengembangan Bisnis Dengan Business Model Canvas. Jurnal MANOVA, 51 - 61, Vol. 4 No. 2, https://doi.org/10.15642/manov.v4i2.456.

Umar, H. (2019). Strategic Management In Action. Jakarta: PT Gramedia Pustaka Utama.

Wardhanie, A. P., \& Kumalawati, D. (2018). Analisis business model canvas pada perpustakaan Institut Bisnis dan Informatika Stikom Surabaya dalam meningkatkan kualitas perguruan tinggi. Berkala Ilmu Perpustakaan dan Informasi, 124-132, Vol. 14 No. 2, https://doi.org/10.22146/bip.32247. 